\section{Newspaper Mulches for Suppressing Weeds for Organic High-tunnel Cucumber Production}

\author{
Elsa Sánchez ${ }^{1,2,4}$, William J. Lamont, Jr. ${ }^{3}$, and Michael D. Orzolek ${ }^{3}$
}

AdDitional INDEX wORDs. straw, biodegradable mulch, Cucumis sativus, weed management

SUMMARY. Mulches usable in organic production were evaluated in high tunnels for their ability to suppress weeds. Mulch treatments were shredded newspaper, sheets of newspaper, straw, and a no-mulch control that was weeded once. Four cucumber (Cucumis sativus) cultivars were also evaluated. Yields were highest and fruit largest from 'Sweet Marketmore' and lowest from 'Lemon'. Yields were unaffected by mulch treatments. Weed populations were highest in control plots and lowest in those with shredded newspaper. Cultivars did not affect weed populations. Sheets of newspaper degraded the most, followed by shredded newspaper and straw. Yields were not influenced by any mulch treatment, indicating weed populations remained below yield-depressing levels regardless of treatment.

S oil properties on organic farms favor a greater diversity in weed species and reduced weed pressure compared with conventional farms (Ngouajio and McGiffen, 2002). Despite the reduced weed pressure, weeds are frequently cited as the most challenging pest problem on organic farms (Walz, 1999). Weeds are primarily suppressed using a variety of cultural strategies (Zinati, 2002) with herbicide options and use being limited. Cultural management can include the use of organic and inorganic mulches; newspaper is one organic mulch option. Newspaper and other papers are allowable for use in organic production contingent on the exclusion of sheets with glossy or colored inks (U.S. Department of Agriculture, 2007). Newspaper can be a lower cost alternative to straw and plastic mulches. Additionally, newspaper is free of weed seeds (Munn, 1992) which can be an issue with straw mulches. Newspaper is biodegradable (Shogren, 2000) and can be turned into the soil, thus eliminating disposal concerns associated with plastic mulches (Brault et al., 2002; Shogren, 2000). Using

Use of trade names does not imply endorsement of the products named or criticism of similar ones not named.

We thank Kathleen Demchak and James Sellmer for reviewing a draft manuscript.

${ }^{1}$ Department of Horticulture, Pennsylvania State University, 102 Tyson Building, University Park, PA 16802

${ }^{2}$ Assistant professor of horticultural systems management.

${ }^{3}$ Professor of vegetable crops

${ }^{4}$ Corresponding author. E-mail: esanchez@psu.edu. newspaper as mulch can also limit the amount of paper deposited in landfills (Anderson et al., 1995). Lastly, paper mulches are a renewable technology (Shogren, 2000).

Trials have evaluated the effectiveness of newspaper mulches for weed suppression in various crops in field settings (Calkins et al., 1996; Carter and Johnson, 1988; Grassbaugh et al., 2004; Monks et al., 1997; Munn, 1992; Warmund et al., 1995). Difficulties in working with newspaper mulches were encountered in many of these trials. Windy or dry conditions in the field have complicated anchoring and managing these mulches (Calkins et al., 1996). Additionally, field environmental conditions promote degradation of newspaper (Carter and Johnson, 1988; Monks et al., 1997; Munn, 1992) and other paper mulches (Weber, 2003). Paper mulches have been treated with various substances including polymer coatings, vegetable oils, and elemental sulfur to delay degradation and facilitate management (Anderson et al., 1995; Shogren, 2000; Weber, 2003); however, the effectiveness of treated paper mulches for suppressing weeds has varied (Shogren, 2000; Weber, 2003).
The high-tunnel environment may be favorable for using newspaper mulches. Weed populations are lower in high tunnels than in the field (visual observation; Waterer, 2003), because soil moisture levels are more easily regulated as a result of the exclusion of rain combined with the extensive use of drip irrigation. Additionally, the high tunnel structures limit environmental factors, including wind and rain (Burkhart, 2002), which can delay the degradation of organic mulches and facilitate their application and management. This trial was conducted to evaluate newspaper mulches for weed suppression in a cucumber crop in high tunnels under organic management.

\section{Materials and methods}

This study was conducted at the Russell E. Larson Research and Education Center, Rock Springs, PA, in four $17 \times 36-\mathrm{ft}$ high tunnels constructed using the Penn State design (Lamont et al., 2002). These high tunnels have been managed since 2003 following the National Organic Standards (U.S. Department of Agriculture, 2007).

Cultivars evaluated were 'Sweet Marketmore', 'Prolific', and 'Diva', which are slicing cucumbers, and 'Lemon', which is a specialty heirloom with a unique yellow skin (Table 1). Organic seed was planted into moistened soilless medium (Johnny's 512 mix; Johnny's Selected Seeds, Winslow, ME) in 50-cell plug flats (Johnny's Selected Seeds) on 23 May 2005 and 2006. Flats were then placed in a high tunnel under organic management and watered to field capacity when the medium surface was dry.

The soil type in the high tunnels was a Hagerstown silt loam. Before planting, a dairy and food scrap-based compost (obtained each year) and a granular $5 \mathrm{~N}-0.4 \mathrm{P}-0.8 \mathrm{~K}$ fertilizer, each at a rate of $100 \mathrm{lb} /$ acre of $\mathrm{N}$, were applied and soil incorporated to

\begin{tabular}{lllc}
\hline $\begin{array}{l}\text { Units } \\
\text { To convert U.S. to SI, } \\
\text { multiply by }\end{array}$ & U.S. unit & SI unit & $\begin{array}{l}\text { To convert SI to U.S., } \\
\text { multiply by }\end{array}$ \\
\hline 0.3048 & $\mathrm{ft}$ & $\mathrm{m}$ & 3.2808 \\
0.0929 & $\mathrm{ft}^{2}$ & $\mathrm{~m}^{2}$ & 10.7639 \\
2.54 & inch(es) & $\mathrm{cm}$ & 0.3937 \\
0.4536 & $\mathrm{lb}$ & $\mathrm{kg}$ & 2.2046 \\
1.1209 & $\mathrm{lb} / \mathrm{acre}$ & $\mathrm{kg} \cdot \mathrm{ha}^{-1}$ & 0.8922 \\
0.9072 & ton $(\mathrm{s})$ & $\mathrm{Mg}$ & 1.1023
\end{tabular}


Table 1. Total marketable yield and average weight and number of four cucumber cultivars produced in organically managed high tunnels in 2005 and 2006.

\begin{tabular}{|c|c|c|c|c|c|c|c|}
\hline \multirow[b]{2}{*}{ Cultivar } & \multirow[b]{2}{*}{ Seed source } & \multicolumn{2}{|c|}{$\begin{array}{l}\text { Marketable yield } \\
(1 \mathrm{~b} / 5 \text { plants })^{\mathrm{z}}\end{array}$} & \multicolumn{2}{|c|}{$\begin{array}{l}\text { Average fruit } \\
\text { wt (lb) }\end{array}$} & \multicolumn{2}{|c|}{ Fruit (no. $/ 5$ plants) } \\
\hline & & 2005 & 2006 & 2005 & 2006 & 2005 & 2006 \\
\hline Sweet Marketmore & Seeds of Change (Santa Fe, NM) & 46.2 & $26.0 \mathrm{a}^{\mathrm{y}}$ & $0.69 \mathrm{a}$ & $0.56 \mathrm{a}$ & 57.4 & $46.3 \mathrm{a}$ \\
\hline Diva & $\begin{array}{l}\text { Johnny's Selected Seeds } \\
\text { (Winslow, ME) }\end{array}$ & 35.5 & $18.2 \mathrm{~b}$ & $0.63 \mathrm{~b}$ & $0.52 \mathrm{~b}$ & 54.2 & $34.7 \mathrm{~b}$ \\
\hline Prolific & Seeds of Change & 37.7 & $22.5 \mathrm{ab}$ & $0.61 \mathrm{~b}$ & $0.50 \mathrm{~b}$ & 61.8 & $44.6 \mathrm{ab}$ \\
\hline
\end{tabular}

${ }^{\mathrm{z}}$ Values are the mean of four replications. $1 \mathrm{lb}=0.4536 \mathrm{~kg}$.

'Values followed by different letters within years are significantly different using Duncan's LSD test at the $5 \%$ level.

a depth of 12 inches (24 June 2005 and 29 June 2006). On 27 June 2005 and 30 June 2006 seedlings were hand planted in each high-tunnel into four rows spaced on 4-ft centers. Five seedlings of each cultivar were planted 18 inches apart within the row and were staggered on each side of a drip irrigation line for a total population of 80 plants per hightunnel. Plants were not provided support and were allowed to vine on the ground. One inch of water per week was supplied to the plants via drip irrigation. Pesticides were not used in the trial.

Mulch treatments were 1) wheat straw (Triticum aestivum) grown at the Russell E. Larson Research and Education Center; 2) shredded newspaper $(0.5$-inch strips of varying lengths) from the Center County Municipal Waste Facility, State College, PA; and 3) sheets of newspaper obtained gratis from a local recycling drop-off center. The shredded newspaper used was evaluated by personnel at the organic certifying agency, PA Certified Organic, and deemed allowable. Each mulch treatment was applied to a single row in each high tunnel on 6-7 July 2005 and 10-11 July 2006. Straw and shredded newspaper mulches were applied by hand in a 2 -ft-wide band 4 to 6 inches thick over each row. Sheets of newspaper were applied in a 2 -ft-wide band five sheets thick. Water was applied to both newspaper-based treatments and small amounts of soil were placed on the edges of the sheets of newspaper to anchor the mulches. One row in each tunnel was left bare to serve as a control. The control treatment was hand weeded once, $\approx 1$ month after transplanting before the period of rapid vine growth.
Mulches were removed from each high-tunnel after the growing season. Degradation of the mulches was evaluated weekly after application using an 11 -point visual rating scale where 0 point indicated no degradation and 10 points indicated complete degradation. Weed populations were also evaluated weekly using an 11point visual rating scale with 0 point indicating the absence of weeds and 10 points indicating complete ground coverage with weeds.

Cucumbers were harvested, counted and weighed three times a week from 27 July to 9 Sept. 2005 and 31 July to 8 Sept. 2006. 'Diva', 'Sweet Marketmore', and 'Prolific' fruit were harvested when they reached 6 inches long and had lost their ridges. 'Lemon' fruit were harvested when they reached 3 to 4 inches long and became light yellow in color. After harvest, cucumbers were sorted into marketable and unmarketable categories, with misshapen and blemished fruit considered unmarketable.

\section{Statistical design and analysis}

A split-plot design was used with mulches applied to whole plots. Subplots consisted of the cucumber cultivars arranged in a randomized complete block with four replications. Each tunnel contained one replication. Whole plots were single $30 \times$ $2-\mathrm{ft}$ rows in each tunnel. Subplots were $7.5 \times 2$-ft areas planted with five plants. Treatments were randomly assigned each year of the trial. Data were analyzed with General Linear Model analysis of variance using SAS (version 9.1.3; SAS Institute, Cary, $\mathrm{NC}$ ). When significant differences at $P \leq 0.05$ were detected, Duncan's LSD test was used to separate means.

\section{Results and discussion}

YIELDS. More than 99\% of cucumbers were marketable. In 2005, marketable yields did not differ by cultivar (Table 1). In 2006, marketable yields were higher from 'Sweet Marketmore' than 'Lemon' and 'Diva'. For both years, cucumbers were largest from 'Sweet Marketmore' followed by 'Diva' and 'Prolific', and smallest from 'Lemon'. 'Lemon' reaches maturity at 3 to 4 inches long compared with 6 inches, which is common for slicing cucumbers. For this reason a lower average fruit size was to be expected. In 2005 , the number of cucumbers did not differ by cultivar. In 2006, more cucumbers were harvested from 'Sweet Marketmore' than 'Diva'. The number of 'Prolific' and 'Lemon' cucumbers was statistically similar to 'Sweet Marketmore' and 'Diva'. In general, lower yields were encountered in 2006 versus 2005, including a lower number of cucumbers. This may be related to successive cucumber culture. Four high tunnels were available for this study and for sound replication they were all used both years. Therefore, cucumbers were successively cropped in 2005 and 2006a practice discouraged in commercial production because it can lead to heightened pest populations (Capinera, 2005; Cunfer et al., 2006; Siegies and Pritts, 2006). Anthracnose (Colletotrichum orbiculare), gummy stem blight (Didymella bryoniae), and powdery mildew (Sphaerotheca fuliginea) were observed in both years of the trial and were visually more prevalent in 2006. Colletotrichum orbiculare and D. bryoniae overwinter on plant debris (Zitter et al., 1996), which could have resulted in increased disease pressure in 2006. 
Yields were not influenced by the mulch treatments in either year (data not shown). The influence of mulches on yield is dependent on the crop grown. Straw or newspaper mulches resulted in higher yields compared with bare ground culture of tomato [Solanum lycopersicum (Grassbaugh et al., 2004; Munn, 1992)], soybean [Glycine max (Munn, 1992)], and raspberry [Rubus idaeus (Warmund et al., 1995)] crops. Straw mulch has been inconsistent for increasing yields of potato (Solanum tuberosum) and watermelon [Citrullus lanatus var. lanatus (Johnson et al., 2004)], and sheets of newspaper did not increase eggplant (Solanum melongena) yields compared with a no-mulch control, despite being more effective for managing weeds (Carter and Johnson, 1988). Mulches modify the microenvironment surrounding crops differently depending on mulch properties, environmental conditions, and management practices; however, in general, organic mulches result in cooler and moister soil compared with bare ground (Johnson et al., 2004; Munn, 1992). The extent that this modified microenvironment affects crop growth has been linked with water availability where water stress increases the effectiveness of mulches (Carter and Johnson, 1988; Kirnak and Demirtas, 2006). In this trial, it is thought that adequate water was supplied to plants via drip irrigation, which may have limited the effectiveness of the mulches in increasing yield over the control.

WeEds. Predominant weeds present were pigweed (Amaranthus spp.), hairy galinsoga (Galinsoga ciliata), and grass species-largely foxtail (Setaria spp.), fall panicum (Panicum dichotomiflorum), and crabgrass (Digitaira spp.). In both years, weed populations were highest in control plots and lowest when shredded newspaper was used (Table $2)$. Newspaper sheets and straw mulch provided intermediate weed suppression. Shredded newspaper has been found to provide superior weed suppression compared with straw and no mulch in one trial (Munn, 1992). In another trial, straw and newspaper resulted in similar weed populations that were less than plots with no mulch (Warmund et al., 1995).
The cultivar of cucumber grown did not affect weed populations (data not shown). Additionally, yield parameters were unaffected by mulch treatments. Excessive weed populations can decrease cucumber yields (Berry et al., 2006) but, if managed at critical times, populations can be limited and yields may not be depressed, as has been observed with other crops (Johnson et al., 2004; Pritts and Kelly, 2001). In this study mulches were applied 10 to $11 \mathrm{~d}$ after planting, when weeds were just beginning to emerge. Additionally, control plots were hand weeded 1 month after transplanting cucumbers. All the mulches were effective at suppressing weeds (e.g., weed ratings as low as 1.2 points), but did not result in yields higher compared with the no-mulch control. Weed populations were maintained below yielddepressing levels based on marketable yield data. This indicates that the weeds present in this trial (pigweed, hairy galinsoga, and grass species) were managed at critical times with all treatments - in the early season and within the first month after planting. Also, applying shredded newspaper and straw at a depth of 4 to 6 inches and sheets of newspaper five sheets thick was adequate for managing weed populations.

Weed populations were greater in the 2005 growing season than in 2006. During the transition to organic production, farming systems undergo changes in soil properties, resulting in increased weed species diversity and decreased weed populations (Ngouajio and McGiffen,

Table 2. Effect of organic mulches on end-of-the-growing-season weed populations in organically managed high tunnels in 2005 and 2006.

\begin{tabular}{lcc}
\hline & \multicolumn{2}{c}{$\begin{array}{c}\text { Weed rating } \\
(\mathbf{0}-10\end{array}$} \\
\cline { 2 - 3 } scale $)^{\mathrm{z}}$
\end{tabular}

${ }^{z}$ Ratings are the mean of four replications and are based on a visual rating of a $30 \times 2$-ft area $(9.1 \times 0.6 \mathrm{~m})$ and using a scale of 0 to 10 points where 0 point is no weeds present and 10 points is complete ground coverage by weeds.

yalues followed by different letters within years are significant using Duncan's LSD test at the 5\% level.
2002). For example, composts, manures, and green manures, used primarily for nutrient management, can increase the soil organic matter content and $\mathrm{pH}$, creating an environment conducive to soil microbes, which colonize weed seeds (Ngouajio and McGiffen, 2002). This change in soil properties occurs over time. In 2005, the high tunnels had been under organic management for about 1.5 years. The elapsed time to the 2006 growing season and subsequent changes in soil properties resulting from the additional use of compost and green manure crops may have resulted in lower weed populations in 2006.

Mulch degradation. By the end of the growing season in each year, sheets of newspaper suffered the most degradation followed by shredded newspaper and straw (Table $3)$. Just as observed with weed populations, the cucumber cultivar grown did not influence mulch degradation (data not shown). Shredded newspaper was more effective for suppressing weeds despite being more susceptible to degradation than straw. Both of these mulches were applied at the same depth, indicating that for the shredded newspaper this depth was adequate to compensate for degradation. It was observed that shredded newspaper, once wet, created a dense mat that virtually excluded light penetration. Straw mulch, although limiting light penetration, did not exclude it in small areas, which may have promoted weed seed germination and growth.

Table 3. Degradation at the end of the growing season of mulches used for managing weed populations in organically managed high tunnels in 2005 and 2006.

\begin{tabular}{lcc}
\hline & \multicolumn{1}{c}{$\begin{array}{c}\text { Mulch } \\
\text { degradation } \\
\text { rating } \\
\text { Mulch }\end{array}$} & \multicolumn{2}{c}{ (0) } & scale $)^{\mathrm{z}}$ \\
\cline { 2 - 3 } Newspaper sheets & $5.8 \mathrm{a}^{\mathrm{y}}$ & $\mathbf{2 0 0 6}$ \\
\hline Shredded newspaper & $4.0 \mathrm{~b}$ & $2.0 \mathrm{~b}$ \\
Straw & $1.0 \mathrm{c}$ & $1.0 \mathrm{c}$ \\
$P$ value & $<0.0001$ & $<0.0001$ \\
\hline
\end{tabular}

${ }^{z}$ Ratings are the mean of four replications and are based on a visual rating of a $30 \times 2$ - $\mathrm{ft}$ area $(9.1 \times 0.6 \mathrm{~m})$ and using a scale of 0 to 10 points where 0 point is no degradation and 10 points is complete degradation. 'Values followed by different letters within years are significant using Duncan's LSD test at the $5 \%$ level. 
Sheets of newspaper excluded light; however, they suffered the most degradation and resulted in higher weed populations than shredded newspaper for both years and straw in 2005. Degradation occurred primarily along the edges of the sheets of newspaper, and weeds in these treatment plots were predominantly present where the sheets overlapped.

All mulch treatments used in this study, including the no-mulch control, suppressed weeds to below yield-depressing levels. Additionally, managing these mulches was not complicated by environmental factors to the extent that has been described in the field. The cost of the mulch favors the use of sheets of newspaper (free) over shredded newspaper $(\$ 40$ per ton or $\approx \$ 1.00 / 60-\mathrm{ft}^{2}$ row) and straw (\$100 to $\$ 150 /$ ton or $\approx \$ 1.80 /$ $60-\mathrm{ft}^{2}$ row). Mulching material was not a factor with the no-mulch control; however, these plots were hand weeded once, generating additional labor costs not associated with the other mulch treatments. A complete economic analysis should be performed to account for transportation, handling, application, and weeding costs associated with these treatments.

\section{Literature cited}

Anderson, D.F., M. Garisto, J. Bourrut, M.W. Schonbeck, R. Jaye, A. Wurzberger, and R. DeGregorio. 1995. Evaluation of a paper mulch made from recycled materials as an alternative to plastic film mulch for vegetables. J. Sustainable Agr. 7:39-61.

Berry, A.D., W.M. Stall, B. Rathinasabapathi, G.E. MacDonald, and R. Charudattan. 2006. Smooth pigweed (Amaranthus bybridus L.) and livid amaranth (Amaranthus lividus) interference with cucumber (Cucumis sativus). Weed Technol. 20:227-231.

Brault, D., K.A. Stewart, and S. Jenni. 2002. Growth, development and yield of head lettuce cultivated on paper and polyethylene mulch. HortScience 37:92-94.

Burkhart, E.P. 2002. Utilization of compost in high tunnel cropping systems: Opportunities and challenges. The Pennsylvania State University, University Park, PA, MS thesis.

Calkins, J.B., B.T. Swanson, and D.L. Newman. 1996. Weed control strategies for field grown perennials. J. Environ. Hort. 14:221-227.

Capinera, J.L. 2005. Relationships between insect pests and weeds: An evolutionary perspective. Weed Sci. 53:892901.

Carter, J. and C. Johnson. 1988. Influence of different types of mulches on eggplant production. HortScience 23: $143-145$.

Cunfer, B.M., G.D. Buntin, and D.V. Phillips. 2006. Effect of crop rotation on take-all of wheat in double-cropping systems. Plant Dis. 90:1161-1166.

Grassbaugh, E.M., E.E. Regnier, and M.A. Bennett. 2004. Comparison of organic and inorganic mulches for heirloom tomato production. Acta Hort. 638:171-177.

Johnson, J.M., J.A. Hough-Goldstein, and M.J. Vangessel. 2004. Effects of straw mulch on pest insects, predators, and weeds in watermelons and potatoes. Environ. Entomol. 33:1632-1643.

Kirnak, H. and M.N. Demirtas. 2006. Effects of different irrigation regimes and mulches on yield and macronutrition levels of drip-irrigated cucumber under open field conditions. J. Plant Nutr. 29: 1675-1690.

Lamont, W.J., M. McGann, M.D. Orzolek, N. Mbuga, B. Dye, and D. Reese. 2002. Design and construction of the Penn State high tunnel. HortTechnology 12:447-453.

Monks, C.D., D.W. Monks, T. Basden, A. Selders, S. Poland, and E. Rayburn. 1997. Soil temperature, soil moisture, weed control, and tomato (Lycopersicon esculentum) response to mulching. Weed Technol. 11:561-566.
Munn, D.A. 1992. Comparisons of shredded newspaper and wheat straw as crop mulches. HortTechnology 2:361366.

Ngouajio, M. and M.E. McGiffen. 2002. Going organic changes weed population dynamics. HortTechnology 12:590-596.

Pritts, M.P. and M.J. Kelly. 2001. Early season weed competition reduces yield of newly planted matted row strawberries. HortScience 36:729-731.

Shogren, R.L. 2000. Biodegradable mulches from renewable resources. J. Sustainable Agr. 16:33-47.

Siegies, A.T. and M. Pritts. 2006. Cover crop rotations alter soil microbiology and reduce replant disorders in strawberry. HortScience 41:1303-1308.

U.S. Department of Agriculture. 2007. The National Organic Program. Program standards. 5 Mar. 2007. <www.ams. usda.gov/nop/NOP/standards.html>.

Walz, E. 1999. Final results of the third biennial national organic farmers' survey. 7 Mar. 2007. <http://ofrf.org/ publications/pubs/3rdsurvey_results.pdf $>$.

Warmund, M.R., C.J. Starbuck, and C.E. Finn. 1995. Micropropagated 'Redwing' raspberry plants mulched with recycled newspaper produce greater yields than those grown with black polyethylene. J. Small Fruit Viticult. 3:63-73.

Waterer, D. 2003. Yields and economics of high tunnels for production of warmseason vegetable crops. HortTechnology 13:339-343

Weber, C.A. 2003. Biodegradable mulch films for weed suppression in the establishment year of matted-row strawberries. HortTechnology 13:665-668.

Zinati, G.M. 2002. Transition from conventional to organic farming systems: I. Challenges, recommendations, and guidelines for pest management. HortTechnology 12:606-610.

Zitter, T.A., D.L. Hopkins, and C.E. Thomas (eds.). 1996. Compendium of cucurbit diseases. APS Press, St. Paul, MN. 